\title{
Commentary: Scientists still behaving badly
}

\author{
Thomas A. D’Amico, MD
}

The US Office of Science and Technology Policy has defined research misconduct as "fabrication, falsification, or plagiarism in proposing, performing, or reviewing research, or in reporting research results." ${ }^{1}$ Yet, a survey of thousands of scientists funded by the National Institutes of Health exposed research misconduct in broader and deeper terms, spanning a spectrum, including uncorrected error, bias, conflict of interest (revealed or hidden), inaccurate or statistically flawed analysis, plagiarism, duplicate publication, peer-review fraud, and falsification of data. ${ }^{2}$ Of the 16 behaviors listed on the survey, at least $5 \%$ of scientists self-reported engagement in all but 2 behaviors, more than $10 \%$ of scientists admitted violation of more than half of the behaviors, and $33 \%$ of scientists violated at least 1 behavior. The eventual manifestations of this level of scientific fraud goes beyond the narrow view of each event (perhaps resulting in a retracted article) and includes reporting data that could eventually lead to incorrect medical decisions and to misappropriation of funding (which can be defined as theft).

The first step in addressing this potentially disastrous behavior is recognizing the magnitude of the problem, in all its manifestations and degrees of gravity. But are there solutions? D'Souza and colleagues ${ }^{3}$ summarize the problem succinctly and accurately; more important, they summarize our options and obligations as investigators, coinvestigators, reviewers, surgeons collaborating with industry, or surgeons outside of the realm of the scientific process.

Scientific investigation defines the future of cardiothoracic surgery. In an environment of competition for funding

and for high-impact publications, investigators regularly violate the concept of ethical research, and all forms of research misconduct are increasingly common. The costs of unethical research include fraud related to grant funding, scientific misdirection, academic misrepresentation, and patient safety and outcomes. Although potential solutions may not absolutely prevent all infractions, it is incumbent on all of us to do everything possible to protect research integrity.

\section{References}

1. OSTP Federal Policy on Research Misconduct. Available at: https://ori.hhs.gov/ content/chapter-2-research-misconduct-federal-policies. Accessed January 10, 2020 .

2. Martinson BC, Anderson MC, de Vries R. Scientists behaving badly. Nature. 2005;435:737-8.

3. D'Souza DM, Sade RM, Moffatt-Bruce SD. The many facets of research integrity: what can we do to ensure it? J Thorac Cardiovasc Surg. 2020;160:730-3.

From the Division of Thoracic Surgery, Department of Surgery, Duke University Medical Center, Durham, NC.

Disclosures: Author has nothing to disclose with regard to commercial support.

Received for publication Feb 19, 2020; accepted for publication Feb 19, 2020; available ahead of print March 9, 2020.

Address for reprints: Thomas A. D'Amico, MD, Division of General Thoracic Surgery, Duke University Medical Center, DUMC Box 3496, Duke South, White

Zone, Room 3589, Durham, NC 27710 (E-mail: thomas.damico@ duke.edu).

J Thorac Cardiovasc Surg 2020;160:734

$0022-5223 / \$ 36.00$

Copyright (c) 2020 by The American Association for Thoracic Surgery

https://doi.org/10.1016/j.jtcvs.2020.02.093 